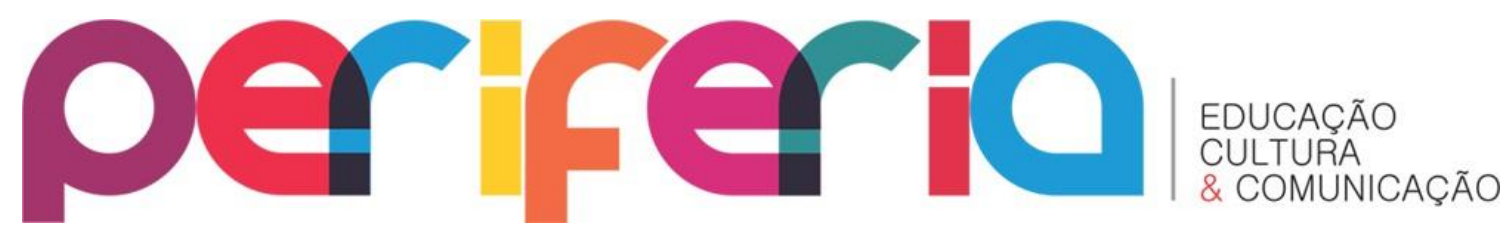

\title{
ESPAÇOS DE LEITURA EM ESCOLAS DO CAMPO: um estudo em turmas multisseriadas
}

\author{
Marcio José de Lima Winchuar ${ }^{1}$ \\ Leilah Santiago Bufrem²
}

\section{Resumo}

Este artigo apresenta parte dos resultados de uma pesquisa maior desenvolvida entre os anos de 2017 a 2020. Como recorte, analisa os espaços de leitura em escolas/turmas multisseriadas de Prudentópolis, município paranaense, situado na região Sul do Brasil. Evidencia e problematiza esses espaços, bem como analisa sob quais determinações estão sendo formados os leitores camponeses do município. Realiza pesquisa bibliográfica e de campo, contando com a participação de dezesseis educadores. Como instrumento de produção de dados, utiliza a entrevista semiestruturada e a observação dos espaços de leitura de cinco escolas multisseriadas. A partir da análise de conteúdo, apresenta como eixos de análise os espaços de leitura, categorizando aqueles mais destacados durante a pesquisa em campo: a sala de aula, o cantinho da leitura, a biblioteca de classe e a biblioteca escolar. Conclui que a sala de aula ainda é o principal espaço de leitura em escolas multisseriadas, junto às bibliotecas de classe e aos cantinhos da leitura que integram esse espaço e têm contribuído com a formação de leitores e com a prática docente.

Palavras-chave: Escolas multisseriadas; Escolas do campo; Espaços de leitura; Leitura.

\footnotetext{
${ }^{1}$ Doutor em Educação pela Universidade Federal do Paraná - UFPR (2020). Mestre em Letras pela Universidade Estadual do Centro-Oeste (2014). Instituição: Universidade Estadual do Centro-oeste do Paraná (UNICENTRO). ORCID iD: https://orcid.org/0000-0001-9486-3111 Email: mwinchuar@gmail.com

2 Doutora em Ciência da Comunicação pela Universidade de São Paulo (USP). Professora Titular aposentada do Curso de Gestão da Informação da Universidade Federal do Paraná (UFPR). Atualmente, é professora visitante A no Programa de Pós-graduação em Ciência da Informação na Universidade Federal da Paraíba (UFPB). Professora permanente na qualidade de Professora Visitante Sênior no Programa de Pós-graduação em Ciência da Informação da Universidade Federal de Pernambuco (UFPE) e permanente no Programa de Pós-graduação em Educação da Universidade Federal do Paraná (UFPR). ORCID iD: https://orcid.org/0000-00023620-0632 E-mail: mwinchuar@gmail.com
} 


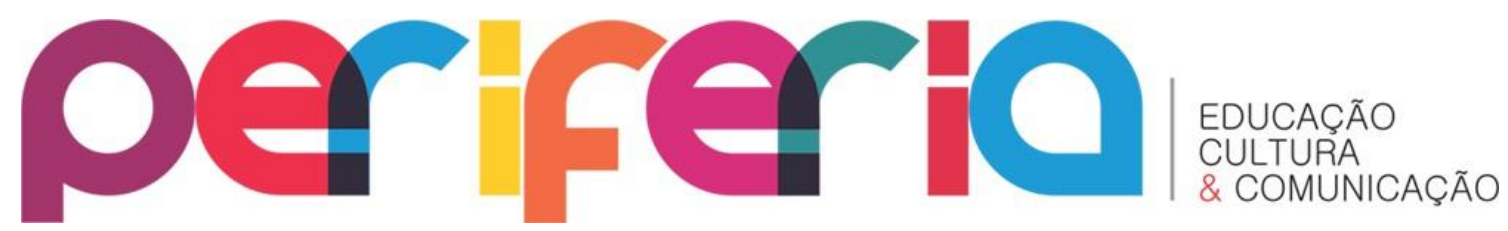

ISSN:1984-9540

DOI: $10.12957 /$ periferia.2021.55242

READING SPACES IN RURAL SCHOOLS:

a study in multi-grade classes

\section{Abstract}

This article presents part of the results of a larger research carried out between the years 2017 to 2020. It analyzes the reading spaces in multi-grade schools/classes in Prudentópolis, a municipality in Paraná in Brazil. It highlights and problematizes these reading spaces, as well as analyzes under which determinations the rural readers of the municipality are being trained. It carries out bibliographic and field research, with the participation of sixteen educators. As a tool for data production, it uses semi-structured interviews and observation of the reading spaces of five multi-grade schools. Based on the content analysis, it uses reading spaces as axes of analysis, categorizing those most highlighted during field research: the classroom, the reading corner, the class library and school library. It concludes that the classroom is still the main reading space in multi-grade schools, along with class libraries and reading corners that integrate this space and have contributed to the training of readers and teaching practice.

Keywords: Multi-grade schools; Rural schools; Reading spaces; Reading.

\section{ESPACIOS DE LECTURA EN ESCUELAS DEL CAMPO: un estudio en clases multigrado}

\section{Resumen}

Este artículo presenta parte de los resultados de una investigación más amplia realizada entre los años 2017 a 2020. Analiza los espacios de lectura en escuelas/clases multigrado en Prudentópolis, municipio de Paraná, ubicado en la región sur de Brasil. Destaca y problematiza estos espacios de lectura, bien como analiza bajo cuales determinaciones se están formando los lectores rurales del municipio. Realiza investigación bibliográfica y de campo, contando con la participación de dieciséis educadores. Como instrumento para la producción de datos, utiliza encuestas semiestructuradas y observación de los espacios de lectura de cinco escuelas multigrado. A partir del análisis de contenido, presenta como ejes de análisis los espacios de lectura, categorizando aquellos más destacados durante la investigación de campo: el aula, el rincón de lectura y la biblioteca de la clase. Se concluye que la 


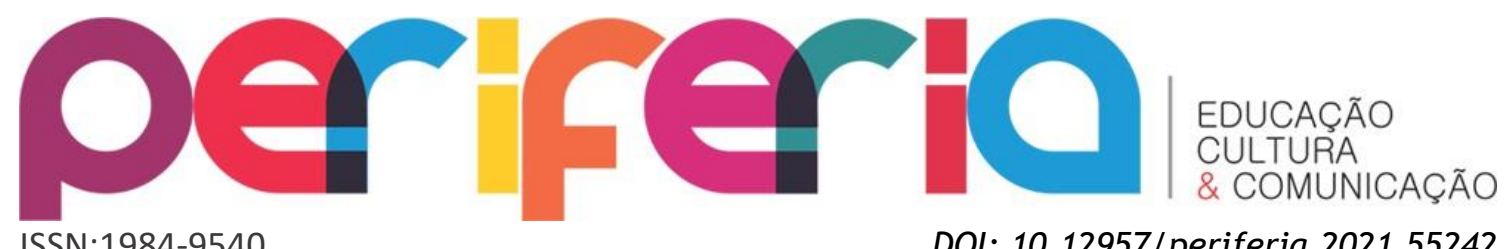

biblioteca de la clase y el rincón de lectura han contribuido a la formación de lectores y a la práctica docente.

Palabras clave: Escuelas multigrado; Escuelas rurales; Espacios de lectura; Lectura.

\section{INTRODUÇÃO}

Este artigo apresenta parte dos resultados de uma pesquisa maior, desenvolvida entre os anos de 2017 a 2020, que analisou sob quais determinações as práticas de leitura ocorrem em escolas e turmas multisseriadas do campo. Neste recorte, preocupamo-nos em discutir os espaços de leitura como determinantes das práticas e partimos de um contexto especial que envolve a multisseriação, presente em todas as regiões do Brasil, principalmente, no campo.

Nos últimos anos, entretanto, vivenciamos inúmeras escolas nuclearizadas e fechadas e, em documento de $2015^{3}$, foi constatado que mais de quatro mil escolas do campo fecharam suas portas em 2014. Já em 2019, de acordo com dados disponibilizados pelo Movimento dos Trabalhadores Rurais sem Terra (MST), com base nos dados do INEP, entre 1997 e 2018, foram fechadas quase 80 mil escolas no campo brasileiro 4 .

A multisseriação tem sido a única alternativa proposta por muitas secretarias municipais de educação para manter escolas que permanecem no campo em funcionamento, tendo como principal justificativa o baixo número de matrículas em determinadas regiões do país. Vale destacar que a multisseriação faz parte da história da educação brasileira e as escolas multisseriadas surgiram após a expulsão dos Jesuítas, vinculadas ao Estado ou

\footnotetext{
${ }^{3}$ Disponível em: https://mst.org.br/2015/06/24/mais-de-4-mil-escolas-do-campo-fechamsuas-portas-em-

2014/\#: :text=S\%C3\%B3\%20em\%202014\%20foram\%20872,seguido\%20pelo\%20Piau\%C3\%AD\%20co m\%20377. Acesso em 10 de outubro de 2020.
}

4 Disponível em: https://mst.org.br/2019/11/28/80-mil-escolas-fechadas-no-campobrasileiro-em-21anos/\#: : :text=No\%20ano\%20de\%202011\%2C\%200,campo\%2C\%20entre $202002 \% 20$ e $\% 202010$. Acesso em 09 de outubro de 2020. 


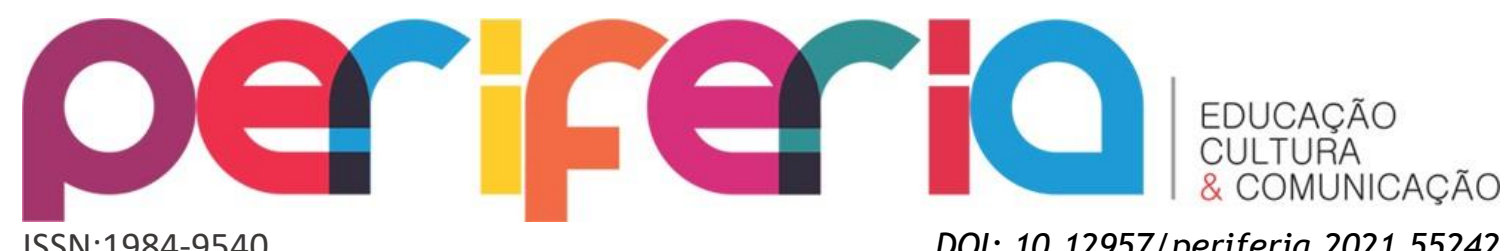

ISSN:1984-9540

DOI: $10.12957 /$ periferia.2021.55242 sem esse vínculo, convivendo com professores ambulantes que de fazenda em fazenda ensinavam as primeiras letras. Nesse âmbito, nas pequenas vilas e/ou lugares pouco habitados, reuniam-se crianças em torno de um professor para poder aprender a ler, escrever e contar (DILZA ATTA, 2003 apud SANTOS; MOURA, 2010).

Historicamente precarizadas, a literatura nos mostra que as escolas/turmas multisseriadas são constituídas pelo trabalho de um único professor com estudantes de diversas idades, séries/anos. No Brasil, essa organização é comum em escolas do campo, marcadas, muitas vezes, por contradições e desafios que vão desde a sua infraestrutura, a sobrecarga de trabalho docente e a falta de formação específica para atuar nesses contextos. Negativizadas perante a sociedade, muitas dessas escolas funcionam em prédios precários, sem iluminação, sem bibliotecas, sem materiais pedagógicos e de leitura suficientes para práticas significativas. 0 trabalho docente não se restringe apenas a atividades didático-pedagógicas, pois desenvolve todas as funções necessárias ao funcionamento da escola, desde matrícula, limpeza, preparo do lanche, reparos gerais, entre outras atividades.

Em meio às condições precárias dos espaços escolares e do trabalho docente, a sala de aula ocupa um lugar de destaque, tendo em vista que dificilmente as escolas multisseriadas contam com outros ambientes destinados especificamente à leitura. Para Freitas (2003), a sala de aula configura-se como o espaço mais famoso da escola, sendo o lugar em que ocorrem as interações, as trocas de ideias, as práticas de leitura, de oralidade, de escrita, sempre obedecendo às finalidades sociais da instituição escolar. Nessa conjuntura, questionamos como se caracterizam os espaços destinados à leitura em escolas/turmas multisseriadas de Prudentópolis, no estado do Paraná (PR).

Considerando esse especial contexto e visando responder esse questionamento, esta pesquisa tem por objetivo analisar os espaços de leitura em escolas multisseriadas de Prudentópolis, com ênfase nas salas de aula, nos cantinhos da leitura e nas denominadas bibliotecas de classe. A pesquisa 


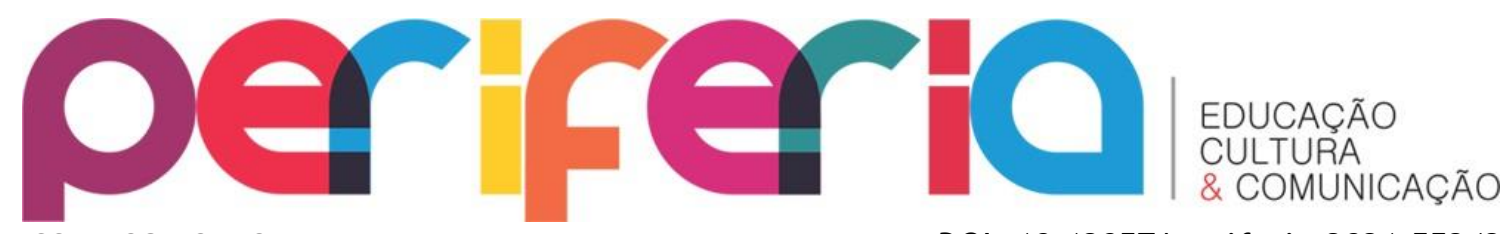

ISSN:1984-9540

DOI: $10.12957 /$ periferia.2021.55242 justifica-se por evidenciar e problematizar os espaços de leitura, a fim de demonstrar como estão sendo formados os leitores camponeses do município, dando visibilidade às escolas e demonstrando suas particularidades no Estado do Paraná.

Por mais que a escola não seja a mesma em cada lugar e seja formada pela diversidade que a envolve em meio a um espaço de tensões e disputas, defendemos, a partir dos estudos de Roseli Caldart, uma escola que independentemente da sua forma de organização, seja um espaço de formação humana e emancipatória. Pensar a escola como lugar de formação humana significa compreendê-la como um ambiente formativo e humanizador dos sujeitos que a fazem: educadores e educadoras, estudantes e comunidades, assumindo uma "matriz de formação multilateral, de construção universal, materializada em cada realidade particular a partir das necessidades sociais e humanas desses sujeitos." (CALDART, 2018, p. 12).

Metodologicamente, trata-se de uma pesquisa bibliográfica e de campo $^{5}$. De acordo com Bufrem $(2011$, p. 5) quanto maior é o conhecimento sobre um determinado tema, mais problemas são levantados pelo investigador que o domina, razão pela qual as leituras preliminares e a busca de pesquisas e informações sobre o objeto de estudo são importantes e foram significativas em nossa pesquisa. Na pesquisa de campo, considerando um total de 474 escolas municipais multisseriadas do campo no estado do Paraná (SILVA; HAMMEL; BORSATTO, 2016), selecionamos Prudentópolis-Pr, uma vez que identificamos ser o município paranaense com 35 escolas com turmas multisseriadas, que atendem a, aproximadamente, 900 estudantes camponeses, fato que já justifica nossa pesquisa.

A história de Prudentópolis é marcada pelo processo de imigração polonesa, italiana, alemã e, com destaque, ucraniana, que no final do século XIX começaram a se instalar na região. O município surgiu da necessidade de povoamento das vastas regiões de mata e do esforço do governo estadual para a construção de estradas férreas e de linhas telegráficas no final do século

5 Aprovada no Comitê de Ética em Pesquisa (COMEP) com o parecer consubstanciado $\mathrm{n}^{\circ}$ 2.705.134. CAEE: 89336818.3.0000.0102 e realizado em 2018 . 


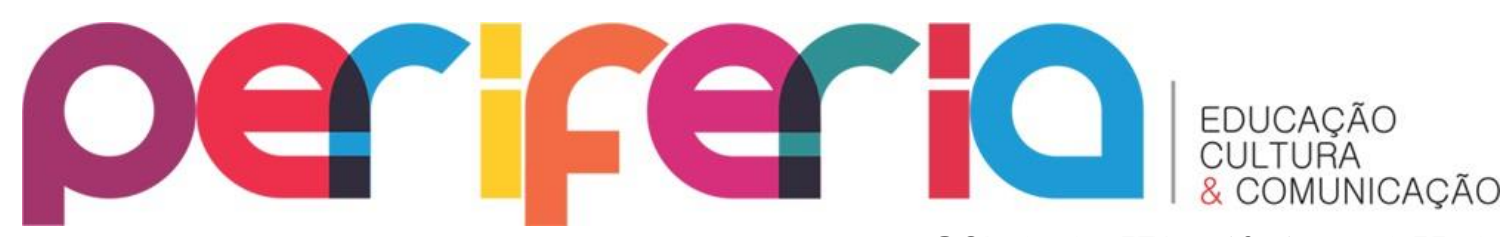

ISSN:1984-9540

DOI: 10.12957/periferia.2021.55242 XIX, conforme demonstra Costa (2013). Localizado na região centro-sul do estado do Paraná, o município conta com uma população estimada de 51.961 habitantes (IPARDES, 2019).

A partir da análise de conteúdo (BARDIN, 2016), tomamos como eixo do estudo os espaços de leitura, categorizando aqueles mais destacados durante a pesquisa: a sala de aula, a biblioteca de classe, o cantinho da leitura e a biblioteca escolar. A categorização é aqui definida como uma operação de classificação de elementos constitutivos de um conjunto por diferenciação e, em seguida, por reagrupamento, com critérios previamente definidos (BARDIN 2016).

Em um universo de trinta e cinco professores, contamos com a aceitação e participação de dezesseis, sendo quinze professoras e um professor $^{6}$. Como instrumento de produção de dados, utilizamos entrevistas semiestruturadas e a observação dos espaços de cinco escolas, tendo como critério principal aquelas com estudantes de diferentes idades e níveis de aprendizagem agrupados em uma mesma turma. Consideramos que esse é um número significativo, tendo em vista que nosso critério de participação não é numérico, mas a "amostra deve permitir que o pesquisador seja capaz de conhecer bem a realidade ou objeto em sua complexidade, intensificando sua busca nas características e qualidades perceptíveis, sem que a generalização dificulte seu propósito" (BUFREM, 2011, p. 9).

Organizamos o artigo da seguinte forma: primeiramente, apresentamos nossa temática e o objetivo do trabalho, conforme vimos na introdução. Em seguida, apresentamos resultados de nossa pesquisa de campo, articulando teoria e prática, evidenciando as contradições e desafios que envolvem a multisseriação, materializada pela própria organização dos espaços escolares, como a sala de aula, a biblioteca de classe, o cantinho da leitura e a biblioteca escolar. Por fim, concluímos o artigo.

\footnotetext{
${ }^{6}$ Nesse artigo, referimo-nos aos participantes como EDUCADORA ou EDUCADOR, seguido de uma letra do alfabeto, tendo em vista questões que envolvem a ética em pesquisa.
} 


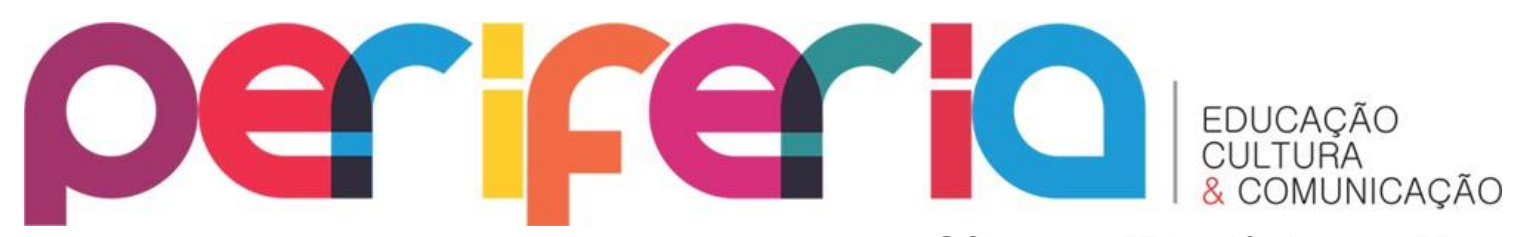

ISSN:1984-9540

DOI: 10.12957/periferia.2021.55242

A sala de aula como espaço de leitura

"O espaço mais famoso da escola é a sala de aula e o tempo mais conhecido é o da seriação das atividades e dos anos escolares. Essa construção obedece a certas finalidades sociais, já que a escola é uma instituição social”, constituída por uma necessidade ligada à formação capitalista, que necessita de uma escola que prepare rapidamente, e em série, recursos humanos para alimentar a produção de forma hierarquizada e fragmentada. A organização seriada se mostra como hegemônica nos diversos espaços escolares brasileiros, fato que reflete na prática docente e na própria organização da sala (FREITAS, 2003, p. 14).

Nessa esteira, o conhecimento foi dividido em disciplinas e distribuído por anos, subdivididos em partes menores que servem para controlar a velocidade de aprendizagem do conhecimento, evidenciando que há uma hierarquia econômica fora da escola e que afeta a constituição das hierarquias escolares. A lógica escolar seriada faz parte da gênese da escola e qualquer outra forma de organizar os processos de ensino e aprendizagem escolarizados é visto de forma negativa e distante de um padrão de referência (FREITAS, 2003).

Sem desconsiderar outros aspectos, principalmente, aqueles relacionados à precarização de muitas escolas do campo, a organização multisseriada pode ser um dos elementos que, historicamente, reforça olhares negativizados. Vale lembrar, entretanto, que há estudos que já demonstram o potencial inerente às escolas do campo, evidenciando que o problema não está em sua forma de organização. Pianovski (2017, p. 196), por exemplo, constata que "não é a composição das turmas multisseriadas que impede a qualificação do ensino, mas a forma de condução do processo de ensino e aprendizagem que vislumbra a junção de séries e consequentemente a fragmentação do trabalho".

No que se refere às práticas de leitura, Winchuar (2020) defende que o trabalho com estudantes de diferentes idades e níveis de aprendizagem em sala de aula potencializa o aprendizado da leitura em um cenário em que um 


\section{periferio}

aprende com o outro, a partir de um processo de interação presente nesses espaços, no entanto, as condições de produção em que as escolas do campo estão inseridas resultam em dificuldades que interferem na efetivação de algumas práticas e, consequentemente, na precarização do trabalho docente.

Nessa conjuntura, insistimos na necessidade de repensar formas de organização da escola do campo, principalmente, porque a escola na "lógica seriada", tomada como referência de ensino, "vem acumulando cada ano milhões de segregados, reprovados, por não seguirem o suposto processo linear, seriado, do ensino dos conhecimentos e dos processos de aprender" (ARROYO, 2010, p. 12).

Ao discutir a escola multisseriada, Hage (2014) salienta a necessidade de transgressão do paradigma multisseriado. Por este enfoque, o autor defende a superação de visões que colocam de um lado a multisseriação como algo negativo e, de outro, como algo que poderia dar certo, já que os pilares que sustentam a seriação estão presentes na multisseriação, tais como a fragmentação, a padronização, a linearidade, a hierarquização, entre outros. Pensar a educação pública do campo é desconstruir esses pilares e construir outros, que possibilitem o pensamento crítico e o desenvolvimento de práticas de leitura de uma forma transformadora e libertadora, pensando o campo como um território de sujeitos que se organizam e lutam.

Nas escolas investigadas, a lógica seriada predomina e se materializa na organização do espaço e nas próprias atividades de leitura, entretanto, mesmo que de forma tímida, práticas que fogem dessa lógica têm ganhado espaço, pois, por mais que sejam comuns salas com carteiras e cadeiras enfileiradas por série/ano e níveis de aprendizagens ${ }^{7}$, há pequenos vestígios de rompimento e algumas atividades em pequenos grupos não seriados, em que todos se sentam juntos, em círculos, no chão ou ao redor da mesa e interagem durante as leituras. Isso nos permite a retomar as ideias de Vigotsky (1988), ao considerar que a formação da criança se dá na interação

\footnotetext{
${ }^{7}$ Ao falarmos em níveis de aprendizagem estamos nos referindo ao fato de que em uma mesma sala de aula nos deparamos com uma pluralidade de saberes, independente da série/anos e/ou idades em que os estudantes se encontram.
} 


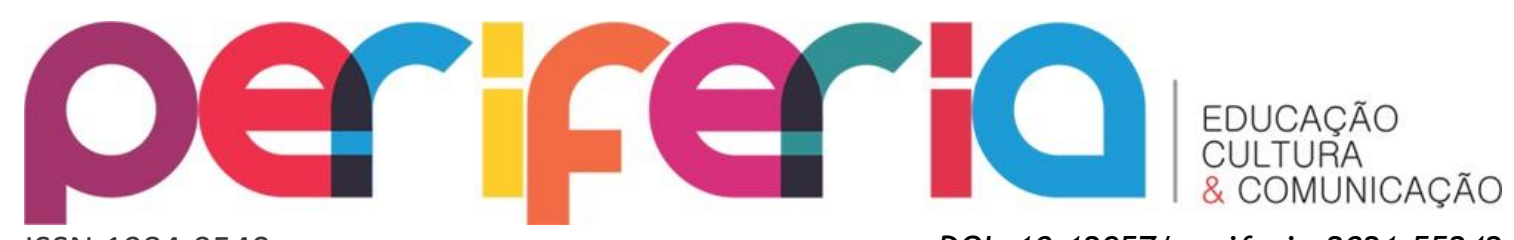

ISSN:1984-9540

DOI: $10.12957 /$ periferia.2021.55242 com o outro, a partir das relações que estabelece. Em meio às práticas de leitura, por exemplo, o processo de ensino e aprendizagem ocorre de forma ímpar, já que os sentidos atribuídos ao texto que se lê são múltiplos.

Winchuar (2020) destaca que além da interação do leitor com o texto, com os personagens e com o autor, há a interação com o outro que está em níveis de desenvolvimento diferentes, seja real ou potencial, o que faz com que algumas crianças consigam realizar determinadas leituras sozinhas e outras somente com a ajuda dos colegas e professores. Na prática, alguns dos relatos ajudam a visualizar como isso ocorre, tais como "os que já sabem ler realizam leituras e ajudam os demais" que ainda não sabem (EDUCADORA N, 2018) e "às vezes o do primeiro lê para o do segundo e o segundo para os do primeiro" (EDUCADORA M, 2018). Isso já demonstra pontos positivos no que se refere à interação entre estudantes de diferentes idades e níveis de aprendizagem, ao longo dos anos iniciais do ensino fundamental.

A partir do contato com o outro e da mediação do professor, as crianças aprendem no jogo de interação, tendo a heterogeneidade da turma como ponto positivo para o processo de ensino e aprendizagem da leitura. Entretanto, a complexidade do trabalho se inicia quando a ânsia de reprodução de um modelo seriado ganha espaço, tomado como referência e impregnado na sociedade como um ideal de escola, em que o saber é dividido, passado por meio de livros, distante da vida. "Não é apenas uma questão de seriado ou não: trata-se de uma concepção de como se organiza todo o trabalho pedagógico, as relações de produção, de conhecimento e de poder, em que a existência de séries é apenas mais um elemento e não o único" (FREITAS, 2003, p. 30). Para o autor, a seriação integra a lógica da escola, sendo tão comum que, muitas vezes, é reafirmada como certa, sem questionamento. A predominância de um modelo seriado e fragmentado faz com que professores e estudantes reproduzam esses elementos cotidianamente, fazendo com que todos os elementos da seriação estejam presentes de forma precária na multisseriação.

Miranda (2011) enfatiza a importância de organizar o espaço da sala de aula multisseriada como um ambiente lúdico, com diversos materiais de 


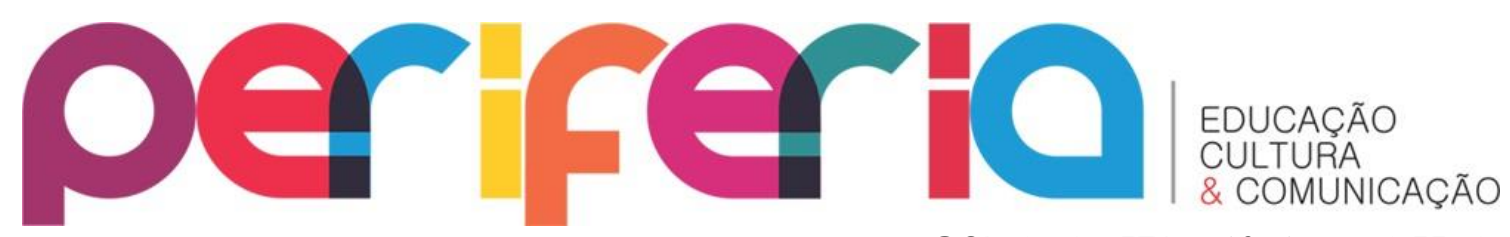

ISSN:1984-9540

DOI: $10.12957 /$ periferia. 2021.55242 leitura a disposição das crianças, fato que se mostrou presente na pesquisa de campo. De forma geral, as salas de aula são formadas por carteiras adequadas ao tamanho das crianças, há quadros de giz, armários multiúso, mapas, alfabeto e tabuada fixados nas paredes, estante com livros didáticos e infantis; murais com nomes e datas de aniversário das crianças e personagens fixados nas paredes.

0 trabalho de campo permitiu identificar que a organização da sala de aula multisseriada pouco se distingue da seriada, caminhando ao encontro de Hage (2014) ao afirmar que a seriação, reivindicada como solução para os problemas que permeiam a multissérie se faz presente nas escolas rurais de forma precarizada. Entretanto, há tentativas de "rompimento" com a lógica seriada em práticas nos cantinhos da leitura, nas bibliotecas de classe e, em alguns casos, em espaços externos a sala de aula, que priorizam o diálogo e a interação.

\section{Cantinhos da leitura como espaço de interação}

O cantinho dedicado à leitura é um espaço comum em escolas do campo, organizado de forma lúdica, com alguns livros infantis e frases de incentivo a leitura que fazem parte da ornamentação do espaço. 0 cantinho da leitura também é conhecido por estante mágica, baú da leitura e, em alguns casos, como biblioteca de sala,

[...] composto com os livros dispostos em estantes, caixas e/ou baús - daí derivando as distintas denominações - na própria sala de aula para leitura individualizada dos alunos. Quanto menores são os alunos, mais bem elaborado é este espaço, podendo ir de almofadas com tapetes, confortáveis divãs, iluminação especial e itens diversos de decoração nas salas da Educação Infantil, até uma simples caixa deixada em um canto da sala de aula dos anos iniciais do Ensino Fundamental (SOUZA; COSSON, 2018, p. 101).

Em escolas do campo, a realidade desses espaços é bem diferente devido à precarização encontrada em algumas escolas. Faltam materiais, 


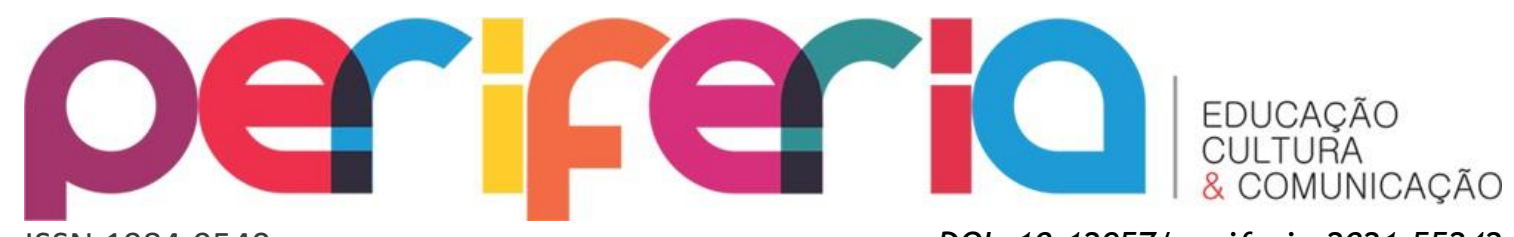

ISSN:1984-9540

DOI: $10.12957 /$ periferia.2021.55242 almofadas, tapetes, livros, estantes e materiais lúdicos. Nessa conjuntura, a dificuldade em diversificar o acervo parece o maior desafio, pois, como relatado pela maioria dos participantes, as crianças gostam de ler e de estar nesse lugar, mas é difícil manter o acervo atualizado. Ao mesmo tempo, a dedicação e o carinho dos docentes na organização do cantinho da leitura são visíveis a partir dos materiais que estão ao seu alcance, como vemos nas imagens abaixo:

IMAGENS 1 e 2: Cantinhos da leitura
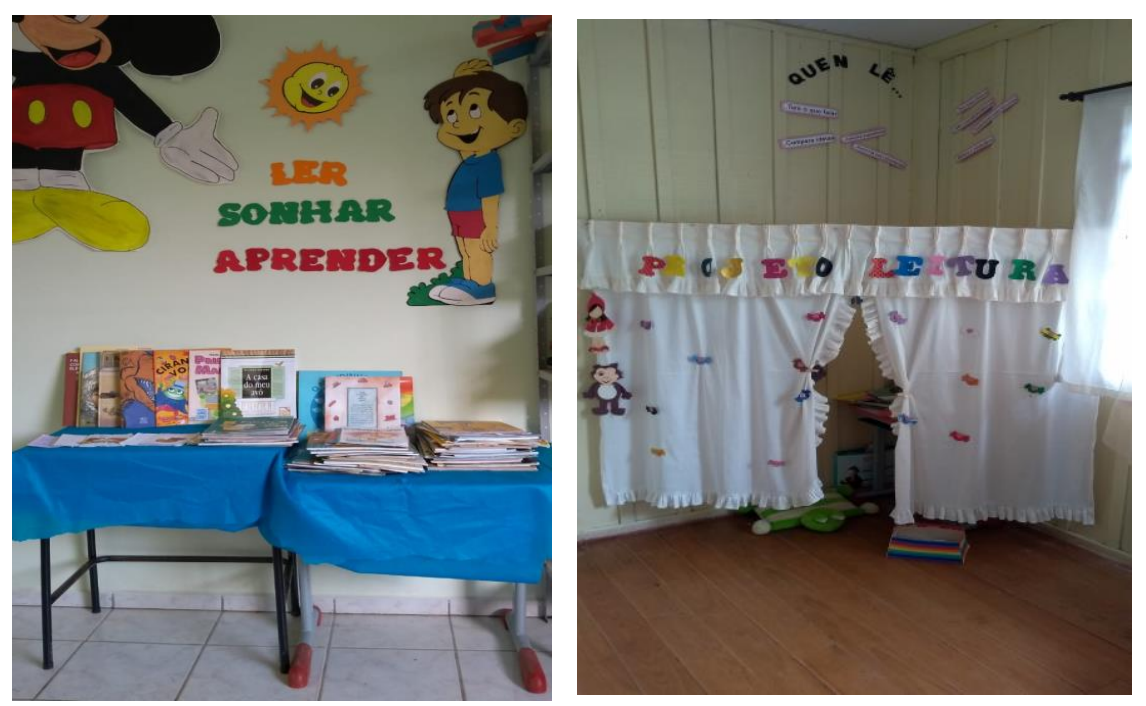

FONTE: acervo do autor, 2018.

O cantinho da leitura das escolas visitadas é composto por um pequeno número de livros de literatura infantil que são acessíveis aos educandos, ou seja, todos tem autonomia e livre acesso a estes materiais durante as aulas. 0 ambiente é organizado de forma que possibilita momentos de fruição e o despertar do interesse pelas histórias. No entanto, a maioria dos materiais integra o acervo da escola durante toda a educação infantil e anos iniciais do ensino fundamental, com poucas reposições, esgotando possibilidades de trabalho com os mesmos livros durante todo esse período. Nesse caso, insistimos na necessidade de investimentos em materiais de leitura, de trocas de livros entre as escolas, de campanhas de arrecadação, visando oferecer aos educandos o acesso a materiais distintos e de qualidade. 


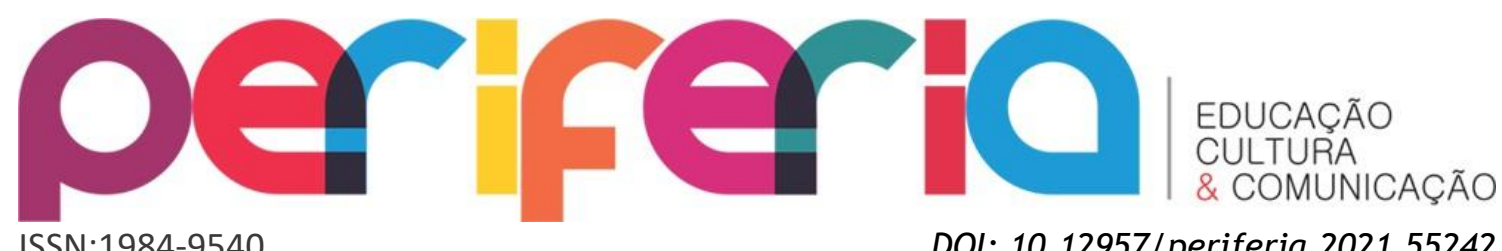

ISSN:1984-9540

DOI: $10.12957 /$ periferia. 2021.55242

$\mathrm{Na}$ especificidade que envolve a multisseriação, o cantinho da leitura é um aliado no trabalho docente. Geralmente é frequentado por aqueles que já terminaram as atividades e podem retirar um livro, ler e folhear, até que uma nova proposta seja indicada pelo professor em meio a suas multifunções. Souza e Cosson (2018, p. 101) fazem uma leitura crítica acerca de propostas de leitura "livre", traduzidas pelo cantinho da leitura tradicional, pois, segundo os autores, raramente há uma preocupação com a qualidade ou diversidade do acervo, bem como com o planejamento de práticas de leitura nesse espaço. Nesse âmbito, a simples oferta e contato com obras é insuficiente para a formação do leitor e "confunde-se o dar acesso ao livro com o trabalho pedagógico de formação do leitor literário".

Nesta pesquisa, identificamos que a falta de mediação e de planejamento das atividades nestes ambientes, quando ocorrem, justificam-se pela concepção de "cantinho da leitura" como um espaço de leitura livre, de deleite, de fruição, o que não quer dizer que atividades planejadas não possam ser livres e fruitivas. Por outro lado é reflexo das condições precárias que envolvem o trabalho docente em meio às multifunções desenvolvidas. Mesmo assim, é notável a preocupação por parte dos educadores das escolas com relação à leitura e aos poucos materiais disponíveis.

Articulados ao cantinho da leitura, Souza e Cosson (2018) afirmam que há objetivos não declarados e declarados pelo professor. 0 primeiro destacase por “[...] manter em silêncio ou pelo menos em outra ocupação os alunos que já terminaram a atividade proposta coletivamente e devem esperar pelos colegas para realizarem a próxima sem perturbar o conjunto da turma" (SOUZA; COSSON, 2018, p. 101). Percebemos que tais objetivos não são via de regra, mas se mostram declarados em alguns dos relatos, tal como cita a Educadora B (2018) ao afirmar que “[...] quando algum já terminou a atividade e a professora e às vezes a estagiária não tem tempo de dar atenção, quando terminou sua atividade vai lá no cantinho da leitura e pega alguma coisinha lá, senta e vai lendo né [...]”.

O material empírico demonstra, também, que a leitura é colocada como um prêmio para aqueles que terminaram as atividades propostas, fato 


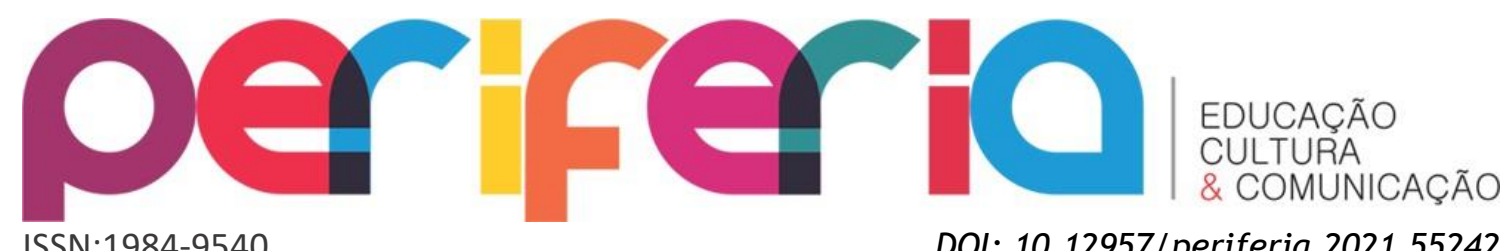

que não apresenta problema, entretanto, aqueles estudantes que não terminaram em tempo hábil dificilmente terão acesso a este "prêmio" e a propostas de leitura deleite, podendo comprometer seu desenvolvimento enquanto leitores, já que terão menos acesso a leitura se comparado aos que conseguiram desenvolver suas atividades em tempo menor.

O segundo objetivo, para Souza e Cosson (2018), destaca-se por oferecer a leitura diretamente em sala de aula e não na biblioteca ou até substitui-la em alguns casos. Nas escolas multisseriadas, o cantinho da leitura é um dos únicos espaços destinados a esta prática envolvendo a ludicidade. Trata-se de um ambiente propício à leitura por proporcionar a interação, a representação, à contação de histórias e o diálogo, instigando a imaginação da criança. É um ambiente que não deve substituir a biblioteca, já que se constituem por finalidades e importâncias sociais diferentes, no entanto, o cantinho da leitura acaba acolhendo práticas que ocorreriam no espaço da biblioteca quando ela não está presente nas escolas.

Os dois objetivos mencionados estão presentes em escolas e turmas multisseriadas, articulados com as vivências e dificuldades docentes. Mesmo assim, esses espaços vão além de uma atividade de leitura que possibilita ao educador dar conta de atividades outras, pois é um momento de uma prática de leitura por fruição do texto em que os estudantes “[...] vão ao cantinho da leitura e escolhem um livro que gostam e leem desenvolvendo sua autonomia" (EDUCADORA B, 2018). As crianças escolhem o momento, o livro, o ritmo de leitura, sem pressão ou pretexto para preencher fichas e responder a perguntas. Além disso, o material empírico demonstrou que também há momentos com práticas planejadas nestes espaços, a partir dos projetos específicos em cada escola, marcadas por práticas de leituras individuais e coletivas, contação de histórias, rodas de conversa, entre outras atividades.

A leitura enquanto fruição é uma maneira de recuperar uma forma de interlocução praticamente ausente das aulas de língua portuguesa, que se define por ler por prazer, por deleite, ler gratuitamente. Isso não quer dizer que a leitura não tenha um resultado, pois o que está em jogo é o desenvolvimento do interesse pela leitura, pelas histórias, pelos livros e é 


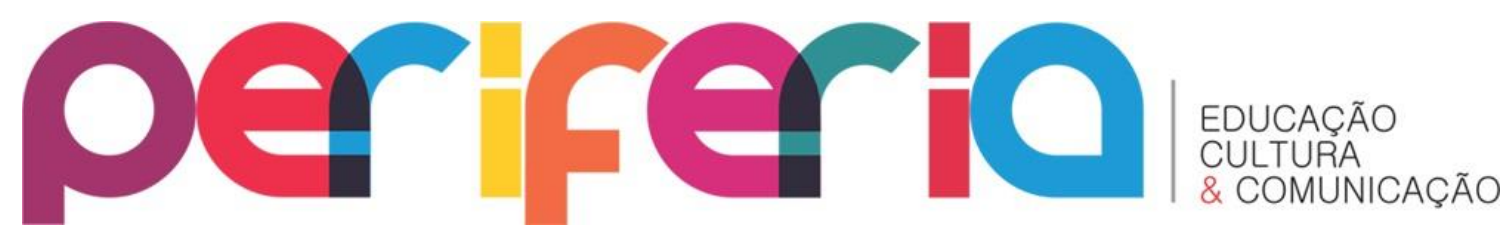

ISSN:1984-9540

DOI: $10.12957 /$ periferia.2021.55242 apenas uma das inúmeras práticas de leitura que ocorrem em sala de aula (GERALDI, 2006).

Em meio a um conjunto de implicações pedagógicas voltadas ao ensino da leitura, Antunes (2003, p. 83) traz a leitura por “pura curtição”. Nessa perspectiva, o processo de formação de leitores deve ser estimulado - com frequência - por meio do "exercício da leitura gratuita, da leitura do texto literário, do texto poético, sem qualquer tipo de cobrança posterior, suscitando assim a leitura pelo simples prazer que provoca”. Acreditamos que esta prática, por meio dos cantinhos de leitura, pode atuar no processo de formação do leitor de forma satisfatória, promovendo práticas que despertem o riso e a descoberta, a criticidade, atribuindo novos sentidos a leitura.

\section{As Bibliotecas de classe como espaços de leitura}

Outro espaço comum dedicado à leitura e ao livro são as Bibliotecas de classe. Todas as salas de aula possuem além dos "cantinhos para leitura", estantes com gêneros e livros de fácil acesso aos educandos. Ferrarezi Jr e Carvalho (2017) destacam como positivo o fato de se ter, a disposição, materiais de leitura ao alcance dos educandos em sala de aula. Segundo os autores, esse material devidamente cuidado e acessível pode ser uma possibilidade de incentivo à formação de leitores na escola, desde que adequados às suas necessidades educacionais.

\footnotetext{
Pequenas bibliotecas de classe ajudam muito no desenvolvimento das atividades dos professores e são um investimento de muito retorno educacional. Uma escola ainda sem condições de ter uma biblioteca ideal para todos os alunos pode começar, opcionalmente, pelo caminho das bibliotecas de turma em que os alunos já podem ter contato com materiais interessantes e bem construtivos para sua formação (FERRAREZI JR; CARVALHO, 2017, p. 65).
}

Como podemos notar nas IMAGENS 3 e 4, esse tipo de espaço apresenta grande importância nas escolas multisseriadas, pois é o lugar em que muitas vezes está todo material de leitura disponível. Muitos professores separam e produzem gêneros específicos e deixam a disposição dos educandos, todavia, 


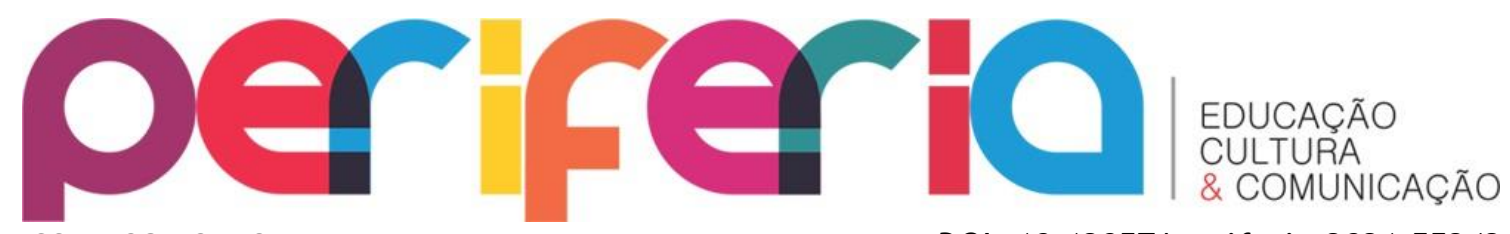

ISSN:1984-9540

DOI: $10.12957 /$ periferia. 2021.55242 devido ao uso contínuo, muitos materiais já se encontram em condições precárias. Mesmo assim, é a possibilidade de trabalho encontrada por professores de escolas do campo do município.

IMAGENS 3 e 4: bibliotecas de sala de sala
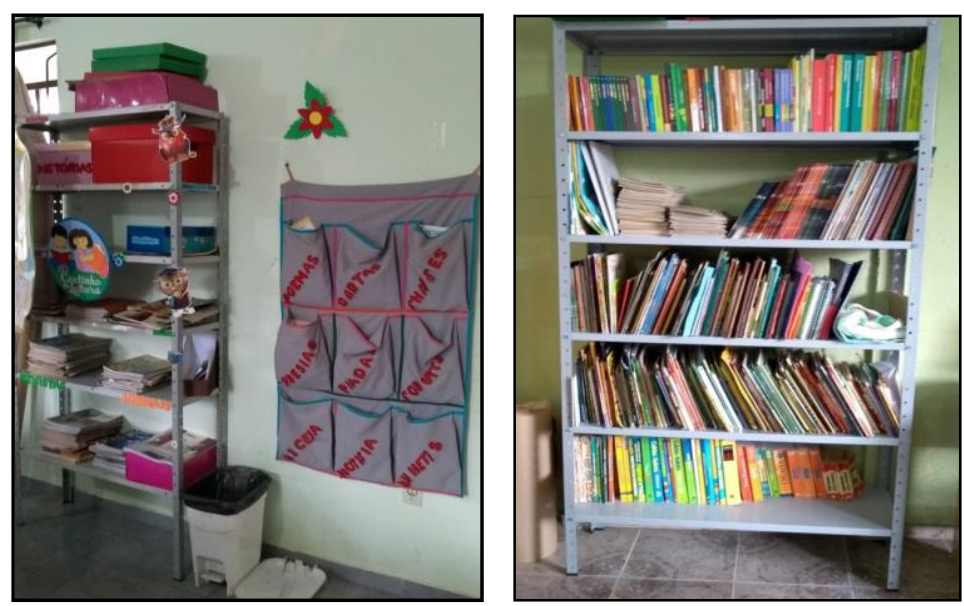

FONTE: acervo pessoal do autor, 2018.

As bibliotecas de classe permitem o acesso, o manuseio e a leitura de materiais de forma acessível e rápida nas escolas e, naquelas com organização multisseriada, são essenciais para o bom andamento das atividades, pois tudo está próximo do professor e dos estudantes: livros, dicionários, gibis, revistas entre outros materiais que compuserem o acervo. Sobre as bibliotecas de turma, Ferrarezi Jr. e Carvalho (2017, p. 64-65) afirmam que

Muitas vezes, precisamos de material de leitura também na sala de aula. Um aluno que termina rapidamente sua tarefa, por exemplo, não deve ficar ocioso, pois o ócio na escola não deve ser visto como um prêmio, mas como perda indesejada de tempo. Além disso, precisamos ter as aulas de leitura na sala e, por outras vezes, precisamos de dicionários ou de outros livros para a execução de tarefas cotidianas (FERRAREZI JR; CARVALHO, 2017, p. 64-65).

Esses espaços auxiliam no trabalho docente, principalmente quando inseridos em uma realidade que envolve as "multifunções" do educador. Os relatos analisados demonstram que essas pequenas bibliotecas, somadas aos cantinhos de leitura têm contribuído com o trabalho e o desenvolvimento das 


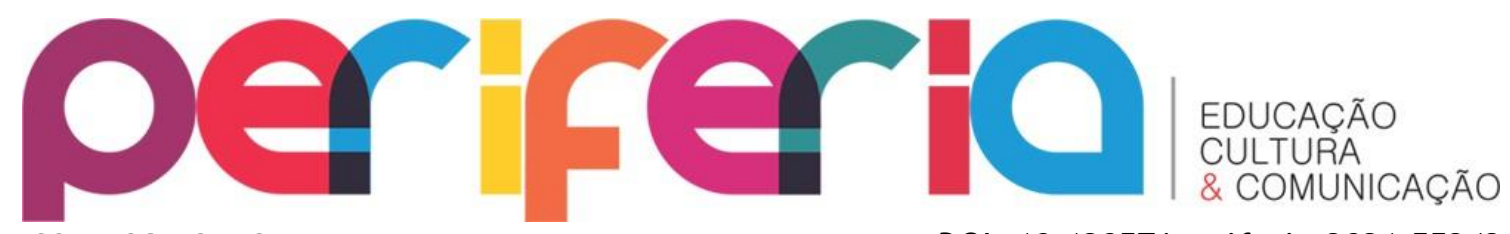

ISSN:1984-9540

DOI: $10.12957 /$ periferia. 2021.55242

atividades estudantis, mesmo que seu acervo não seja integralmente compatível com as necessidades da educação infantil e anos iniciais.

Além dos espaços da sala de aula, duas das escolas apresentam outros ambientes utilizados durante suas práticas. Uma delas conta com uma sala para leitura e brincadeira, denominada brinquedoteca e outra com a geladeira literária, localizada na área externa, conforme observamos na IMAGEM 5:

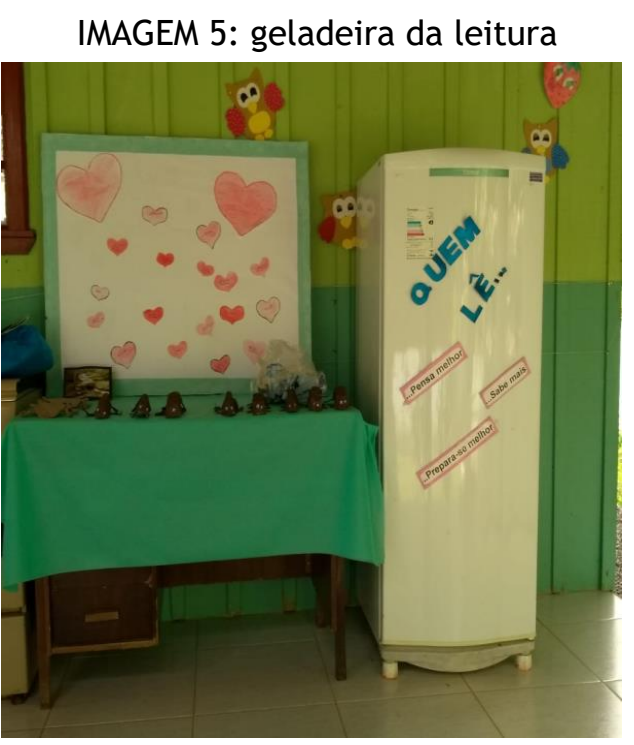

FONTE: acervo pessoal do autor, 2018.

Esses ambientes destinados à leitura proporcionam uma interação maior entre as crianças e com os livros, em um clima agradável para ler. A Geladeira da leitura, assim denominada pela Educadora B (2018), possibilita aos estudantes a realização de práticas fora do horário de aula, uma vez que como ela está no espaço externo da escola e as crianças leem quando aguardam começar as aulas ou quando esperam o transporte escolar.

[...] temos a geladeira da leitura que eles podem pegar livros para ler, às vezes até quando terminam uma atividade ou quando estão esperando começar a aula, eles sentam na escada, na cadeira, no chão, em qualquer lugar para eles estarem lendo, os maiores leem [pausa] hoje, por exemplo, um do terceiro ano estava lendo a historinha do Pinóquio que ele mesmo trouxe de casa, ganhou de alguém né, tava lendo quando eu cheguei para os pequenos (EDUCADORA B, 2018). 


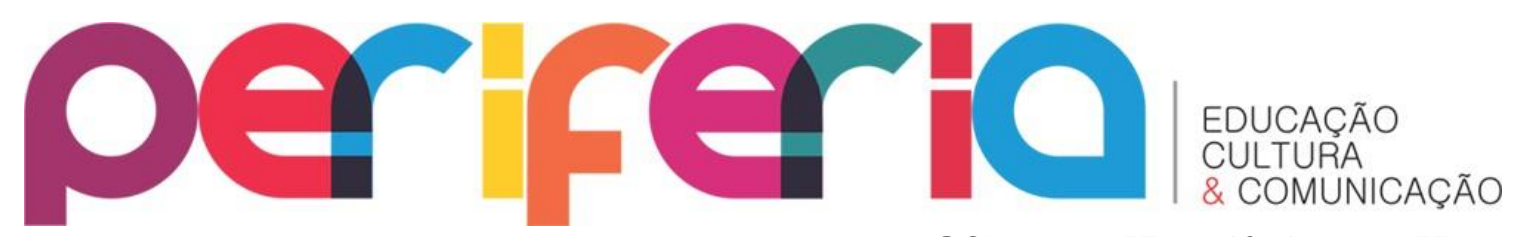

ISSN:1984-9540

DOI: $10.12957 /$ periferia.2021.55242

Projetos como o da Geladeira Literária são comuns em diversas regiões do país, seja em espaço escolar ou em espaços não escolares. Os projetos oportunizam o contato com livros literários por meio da reciclagem e customização de geladeiras que passam a ser atrativas e funcionais para as crianças. Entretanto, na escola em questão, a dificuldade maior está no acervo de livros pouco atualizado, mesmo assim, ela faz parte do cotidiano da escola e tem trazido resultados positivos.

Os espaços externos são utilizados por muitos docentes na tentativa de suprir a necessidade de falta de uma biblioteca e como forma de aproveitar todos os ambientes, fato que tem trazido experiências positivas, como destaca a educadora no relato abaixo:

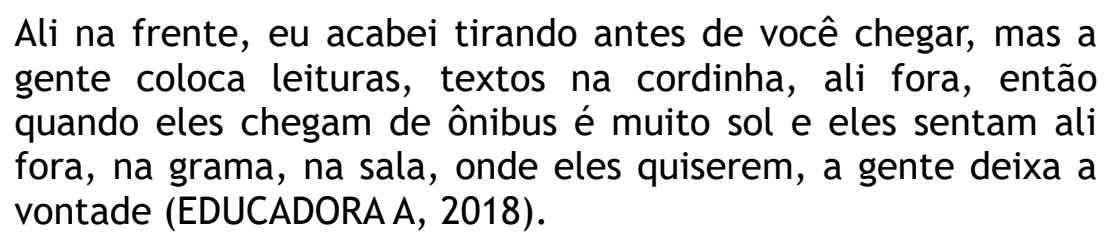

Em muitos momentos as crianças acabam lendo textos diversos organizados na área externa, tais como varais literários, cartazes, murais, cordéis, entre outros textos, fora do horário das aulas, quando aguardam seu início ou ao término, ao esperarem o ônibus escolar para levá-los para casa. A riqueza encontrada graças às observações e experiências inesperadas, abrangeu atividades espontâneas, contando com o próprio interesse e busca dos estudantes pelos materiais de leitura a sua disposição em diversos ambientes, fato que tem ajudado a formar leitores no campo.

O contato com diversos textos e gêneros para a leitura é muito importante na formação do leitor, principalmente, nos anos iniciais de escolarização. De acordo com as orientações pedagógicas para o ensino de 9 anos (PARANÁ, 2010) para que a escola e educadores atendam da melhor forma possível às necessidades reais dos educandos em relação aos conhecimentos sobre sua língua materna, bem como a sistematização de cada gênero é indispensável que ela proporcione aos estudantes o contato com diversos textos, priorizando aqueles mais necessários em suas práticas sociais. 


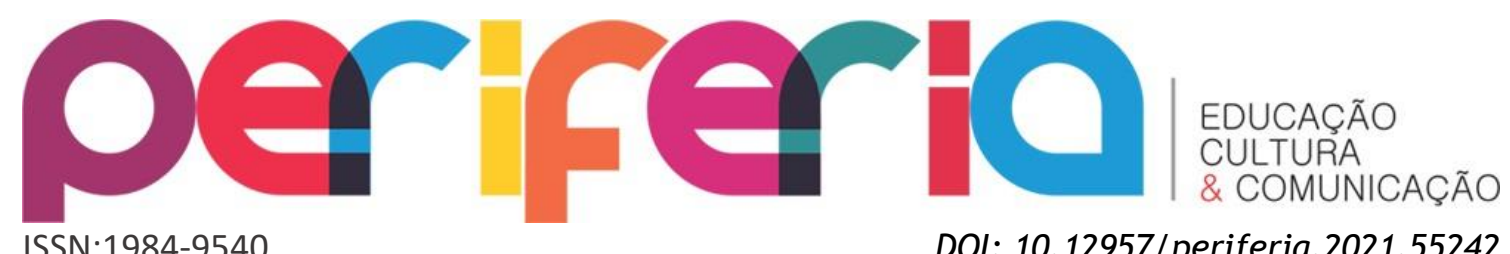

Qual o lugar da biblioteca escolar em escolas do campo?

Em um contexto em que as bibliotecas de turma, os cantinhos da leitura e os ambientes externos são indispensáveis para o desenvolvimento de práticas de leitura, eles não substituem o espaço da biblioteca escolar. A biblioteca é importante na escola, “[...] pois nela disponibiliza-se a informação capaz de promover o processo de aprendizagens nas crianças, não só para pesquisas escolares, mas para a vida toda". A infância é o período apropriado para inserir crianças na formação de cidadãos competentes no uso da informação, bem como para incentivar a leitura reflexiva e fruitiva. Nesse contexto, a biblioteca é o cenário ideal para iniciar e desenvolver essas atividades e a competência informacional (BEDIN, et al., 2016, p. 28).

De igual forma, a biblioteca escolar acaba sendo, para muitas crianças camponesas, a única referência de biblioteca durante a vida, tendo em vista o baixo número de leitores e o difícil acesso a estes espaços no campo. É por essa razão que defendemos sua manutenção em escolas do campo.

A biblioteca escolar não deve servir apenas como complemento didático ao aluno, mas sim, proporcionar um ambiente agradável que disponibilize atividades prazerosas como, por exemplo, o incentivo a leitura por meio da contação e dramatização de histórias, jogos, concursos de poesias, gincanas, entre outras atividades que possibilitem a descoberta de mundos novos, onde a imaginação e a criatividade devem estar sempre em desenvolvimento e aprimoramento (D'ÁVILA; FACHIN, 2016, p. 85).

Pensar a biblioteca nessa perspectiva é tomá-la como um espaço de interação, de produção de sentidos, essencial a criança em seu processo de desenvolvimento, na aquisição de habilidades leitoras e do senso crítico, distanciando-se de concepções que consideram a biblioteca escolar apenas como um espaço de armazenamento de materiais didáticos e livros, mas como um espaço vivo e interativo.

Infelizmente, a precarização de bibliotecas e espaços de leitura, na escola, se faz presente no cenário brasileiro. No início da década de 1990, Silva (1993) já destaca a falta de condições de funcionamento de bibliotecas escolares, os poucos livros na escola e na biblioteca, quando esta existe. Não 


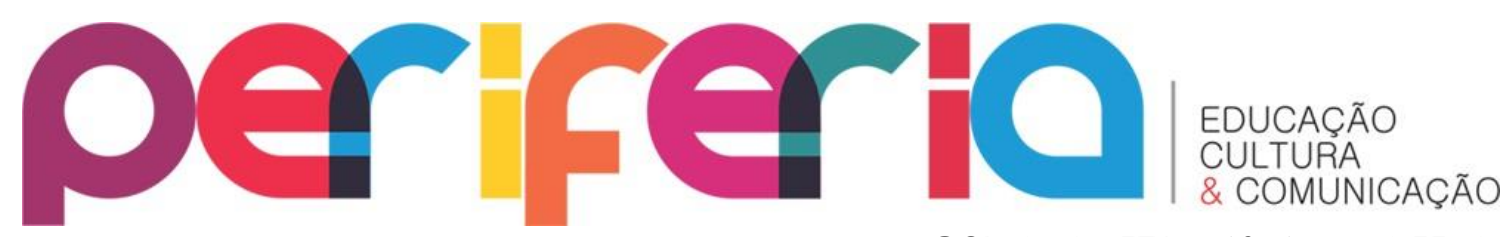

ISSN:1984-9540

DOI: $10.12957 /$ periferia.2021.55242

há espaços específicos para a leitura, não se formam circuitos de leitura e há pouca vinculação entre o que se lê e o que se vive. A leitura existe, muitas vezes, em prol do ensino de gramática normativa e a potencialidade da biblioteca é deixada de lado.

Entre os participantes da pesquisa, 93,8\% afirmaram não ter bibliotecas em suas escolas e 6,2\% dizem que o espaço da biblioteca está sendo utilizado como sala de informática, entretanto, não há computadores funcionando e a escola não conta com acesso a internet. Sobre isso, Ferrarezi Jr. e Carvalho (2017) relatam que há tempos a biblioteca escolar perdeu seu lugar de honra para os laboratórios de informática que também são importantes no processo de ensino e aprendizagem, mas que muitas vezes tomam lugar da biblioteca e a escola não fica nem com a biblioteca e nem com a sala de informática, tendo em vista que além de espaços precários há falta de livros e de computadores que não funcionam e que raramente passam por manutenção.

Com base nas Notas estatísticas do Censo escolar de 2018 (BRASIL, 2019), considerando as escolas públicas e privadas, nos âmbitos federal, estadual e municipal, 48,8\% não possuem biblioteca e/ou sala de leitura ${ }^{8}$. Como se vê, as escolas multisseriadas do município integram essa média, já que $93,8 \%$ dos participantes afirmam que não há biblioteca em suas escolas. A partir disso, questionamos acerca dos impactos dessa realidade em meio às práticas de leitura desenvolvidas pelos docentes e obtivemos as seguintes respostas:

[...] acaba delimitando né, acaba sendo [pausa] o que eles poderiam ter a mais eles não tem né, então, se tivesse uma biblioteca bem equipada né, [é] com vários livros, digamos, só de poesia, só de historinhas, então acabaria ficando mais fácil pra eles optar pelo que eles querem ler [pausa] então hoje posso trabalhar só com literatura, amanhã só com poesia né, então, acaba delimitando, mas que, não que não seja possível né, como eu falei, vou pesquisar, se não tem um livro a gente faz um Xerox, né, então [pausa] é possível desde que você tenha interesse em correr atrás né (EDUCADORA G, 2018).

\footnotetext{
${ }^{8}$ Dados disponíveis em:

http://download.inep.gov.br/educacao_basica/censo_escolar/notas_estatisticas/2018/notas estatisticas_censo_escolar_2018.pdf Avesso em 29 de novembro de 2020.
} 


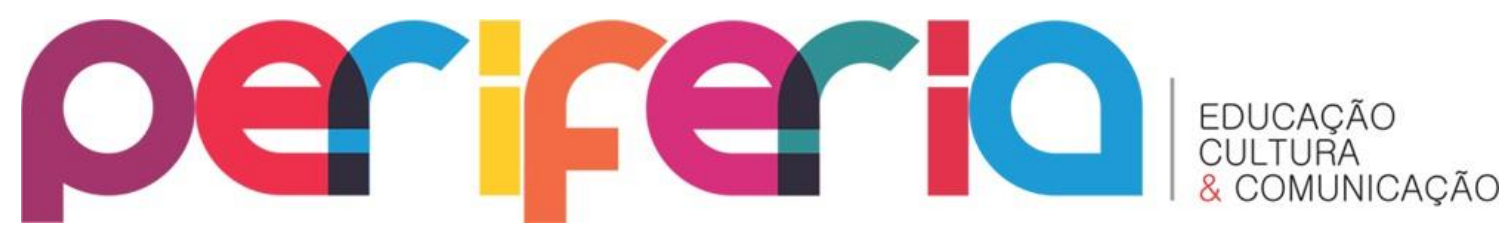

[...] não tem biblioteca. É só o acervo que fica na sala. Tá separado os acervos, mas, às vezes, a gente troca. Isso não interfere na prática, de forma alguma, porque eu acho que o importante é os livros, não a biblioteca em si, a salinha lá da biblioteca, o importante é ter o acervo, pode ser na sala, pode ser em qualquer lugar, o importante é ter o que a criança ler (EDUCADOR 0, 2018).

[...] não tem biblioteca, só tem nossos cantinhos e nossas caixinhas, mas isso não interfere, de maneira alguma, eles têm leitura até demais, eles têm leituras de várias maneiras, então, não interfere. Não adianta ter a biblioteca linda maravilhosa, tem escolas que tem, e o $4^{\mathrm{a}}$ ano não sabe ler, há esse problema em algumas escolas, a gente sabe (EDUCADORA A, 2018).

O fato de não ter biblioteca não afeta a prática, o que afeta é a questão de quantidade, se tivesse um pouquinho mais de material seria melhor, sabe, mas a gente procura trazer os diferentes gêneros pra eles, sabe, às vezes até xerocado, não tem livro e eu trago em Xerox pra eles sabe, para eles conhecerem todos os gêneros né (EDUCADORA L, 2018).

Como se observa, nos relatos, apenas a Educadora $G$ afirma que a falta de biblioteca afeta a prática docente, uma vez que delimita o trabalho e acaba privando o educando do acesso a obras específicas, do espaço e da própria escolha do que lê. Assim, o educador precisa correr atrás de materiais e alternativas para suprir essa falta, demonstrando que a inexistência de uma biblioteca escolar interfere de forma direta no trabalho docente.

Nesse processo, entram em cena os materiais xerocados, conforme discurso da Educadora G e L. Em certos casos, o recorte de livros (apostilas mimeografadas ou xerografadas) "pode se colocar como a única saída possível para o desenvolvimento do estudo. Isto porque a formação e manutenção de bibliotecas escolares ainda não se transformaram em uma forte preocupação na seara educacional" (SILVA, 1998, p. 8 - 9). Entretanto, mesmo sendo a única forma de possibilitar acesso à leitura, os materiais xerocados não substituem os livros, não permitem tocar a obra em seu suporte original, interferindo no processo de produção de sentidos da leitura. 


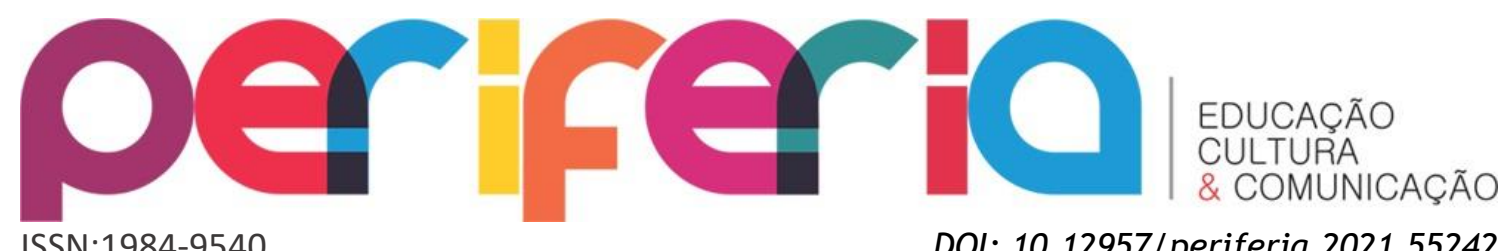

Em 2010, o presidente Luis Inácio Lula da Silva assinou o decreto $12.244^{9}$, que dispõe sobre a universalização de bibliotecas públicas em escolas de todo país. O documento considera biblioteca a coleção de livros e outros materiais videográficos destinados à leitura, à consulta, à pesquisa e ao estudo. Segundo o decreto, os sistemas de ensino deverão desenvolver esforços progressivos para a universalização das bibliotecas escolares e sua implantação no prazo máximo de dez anos. Uma década depois, evidenciamos que ainda há muito a ser feito para que, de fato, bibliotecas públicas e de qualidade sejam realidade em escolas públicas, sobretudo, em contextos do campo.

O material empírico demonstra que a falta de biblioteca em seu espaço físico ou acervo precário acaba obrigando os educadores a desenvolver outras atividades para suprir essa demanda na própria sala de aula. A ênfase maior, nas respostas, está relacionada à falta de livros e não da biblioteca, canalizando para discursos que concebem a leitura desarticulada da biblioteca escolar, como se vê na fala do Educador O (2018), “[...] o importante é os livros, não a biblioteca em si, a salinha lá da biblioteca, o importante é ter o acervo, pode ser na sala, pode ser em qualquer lugar, o importante é ter o que a criança ler".

A biblioteca enquanto espaço de leitura não é concebida como algo essencial para o desenvolvimento das práticas, tampouco como um ambiente de leitura e de produção de sentidos, mas como um espaço de armazenamento de livros. Esses dados são preocupantes, tendo em vista que dificilmente um educador que não vê a importância das práticas de leitura no espaço da biblioteca lutará pela construção e manutenção da biblioteca escolar, caminhando ao encontro de atividades centradas na sala de aula. Isso se agrava ainda mais quando há a ilusão de que a escola, mesmo em meio à precarizações visíveis, é vista por educadores como suficiente em matéria de leitura, conforme o relato da Educadora A, quando afirma que as crianças “têm leitura até demais".

\footnotetext{
${ }_{9}^{9}$ Disponível em: http://www.planalto.gov.br/ccivil_03/_ato2007-2010/2010/lei//12244.htm Acesso em 09 de outubro de 2020.
} 


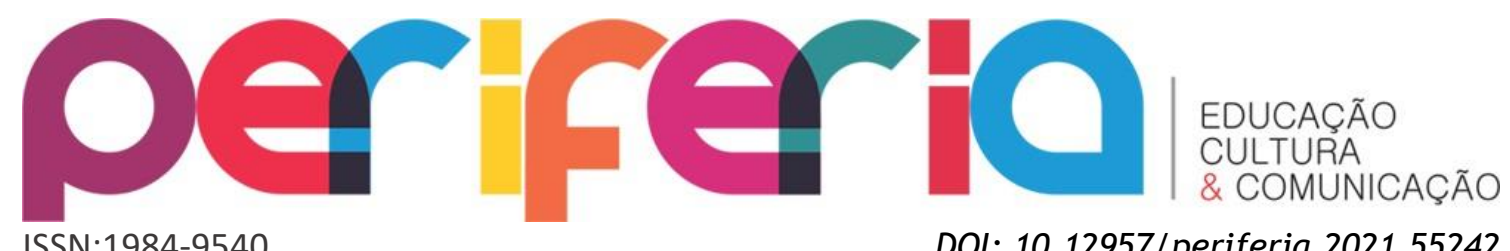

A concepção de biblioteca desarticulada de um espaço de leitura e interação é um fator determinante no processo de formação de leitores em escolas multisseriadas. Nesse sentido, lutar pela biblioteca, pelo livro e pela leitura é uma forma de lutar contra o ensino autoritário, repetitivo e alienante integrado à chamada “lógica da escola”. Se essa luta não partir do educador, dificilmente partirá de outros sujeitos. "A biblioteca deve se transformar num ambiente rico em estimulação sociocultural para a leitura, e com significação para professores, alunos e comunidade”. Enquanto educadores, pais e comunidade não conceberem a biblioteca como este espaço de estímulo e transformação, pouco será feito por/para ela na escola (SILVA, 1998, p. 28).

\section{Considerações finais}

Este artigo, ao analisar os espaços de leitura em escolas multisseriadas de Prudentópolis, apresenta a realidade das escolas do campo do município. Além disso, evidencia a sala de aula como principal ambiente de leitura e, por mais que haja tentativas de rompimento com a lógica seriada na heterogeneidade que envolve a multissérie, a série sempre ressoa como hegemônica em meio às práticas e a própria organização do espaço escolar, a partir de carteiras enfileiradas e das próprias práticas de leitura realizadas.

$\mathrm{Na}$ tentativa de responder sobre quais os espaços destinados à leitura em escolas/turmas multisseriadas, deparamo-nos com escolas sem biblioteca escolar e com um acervo reduzido. Além disso, observamos a predominância de uma concepção de biblioteca apenas como um espaço de armazenamento de livros, fazendo com que não seja vista como essencial para a formação de leitores no campo brasileiro. Diante disso, a biblioteca escolar distancia-se cada vez mais da escola e dos estudantes, passivos perante sua criação e manutenção.

Em contrapartida, as escolas analisadas contam com bibliotecas de classe, formadas por estantes de livros na própria sala de aula. Infelizmente, o acervo, em muitos casos, não é compatível com o número de alunos e as 


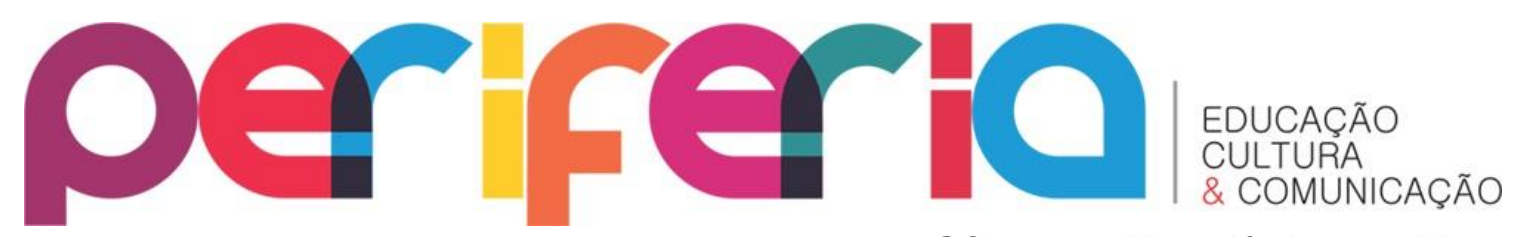

ISSN:1984-9540

DOI: $10.12957 /$ periferia.2021.55242 necessidades da educação infantil e dos anos iniciais do ensino fundamental, obrigando educadores a buscar alternativas outras para suprir essa demanda. É visível a tentativa de proporcionar outros espaços de leitura para as crianças, sempre visando chamar a atenção e despertar o prazer por esta atividade.

Os cantinhos de leitura têm contribuído com a formação de leitores e com o trabalho docente em sala de aula. Como destacamos, além de estimular a autonomia nos estudantes, que ocupam esses espaços e leem de forma livre e prazerosa, permite ao docente o atendimento a todos os estudantes, já que aqueles que terminam as atividades ocupam esse espaço enquanto o professor atende aos demais. Além disso, trata-se de um espaço marcado pela ludicidade, pela interação e pela contação de histórias. É um espaço frequentemente ocupado por educandos e educadores.

As práticas de leitura também ocorrem em espaços externos à sala de aula, tais como o saguão, a área de descanso, o pátio da escola, entre outros, mais ou menos estáveis ou institucionalizados formalmente. Em meio a esses espaços, destacamos a geladeira literária decorada com frases de incentivo à leitura, deixando alguns livros à disposição para que nos momentos fora do horário de aula, os estudantes desenvolvam sua autonomia e busquem os livros. Essa e outras práticas criativas têm trazido resultados positivos e aproximado as crianças de diversos materiais de leitura.

Por fim, a pesquisa permitiu visualizarmos a instituição escolar como um todo: viva e heterogênea, marcada por sujeitos sociais e históricos que ensinam e aprendem a partir de seus saberes, modos de viver e de interagir com e pelo outro. A escola do campo vai além de sua organização espacial, pois materializa um espaço de formação crítica, humana e emancipatória, de leitura de mundo, que tem como foco o protagonismo dos sujeitos que dela fazem parte. Assim, escola e leitura são elementos indissociáveis, pois se aproximam e se complementam na trama que envolve a compreensão da própria vida, marcada por processos de luta e de resistência. 


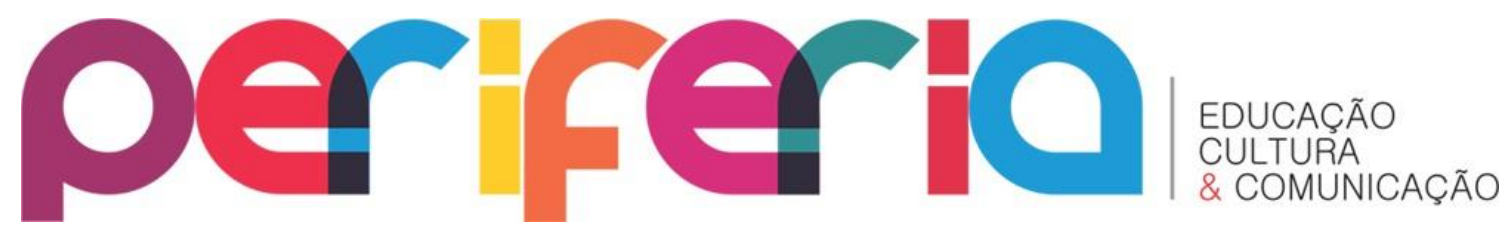

\section{REFERÊNCIAS}

ANTUNES, Irandé. Aula de Português: encontros e interação. São Paulo: Parábola Editorial, 2003.

ARROYO, Miguel G. Escola: terra de direito. In: Escola de direito: reinventando a escola multisseriada / Maria Isabel Antunes-Rocha, Salomão Mufarrej Hage (Organizadores). Belo Horizonte: Autêntica, 2010. p. 9-14.

BARDIN, Laurence. Análise de conteúdo. São Paulo: Edições 70, 2016.

BEDIN, Jéssica; SENA, Priscila Machado Borges; CHAGAS, Magda Teixeira. Biblioteca escolar: um ambiente para o desenvolvimento da competência informacional. In: BLATTMANN, Ursula; VIANNA, Willian Barbosa. Inovação em escolas com bibliotecas. Florianópolis, Dois por Quatro, 2016.

BRASIL. Decreto 12.244 de 24 de maio de 2010. Dispõe sobre a universalização das bibliotecas nas instituições de ensino do País. Disponível em: http://www.planalto.gov.br/ccivil_03/_ato2007-2010/2010/lei/l12244.htm Acesso em 03 de agosto de 2020.

BRASIL, Ministério da Educação e Cultura. Notas estatísticas: Censo Escolar 2018. Brasília, DF, 2019. Disponível em:

http://download.inep.gov.br/educacao_basica/censo_escolar/notas_estatisti cas/2018/notas_estatisticas_censo_escolar_2018.pdf Acesso em $01 \mathrm{de}$ dezembro de 2020.

BUFREM, Leilah Santiago. Questões de metodologia - Parte 1. Revista Eletrônica ATOZ. Curitiba, v. 1, n. 1, p. 4-10, jan./jun. 2011.

CALDART, Roseli Salete. Concepção de Educação do campo: um guia de estudo. In: MOLINA, Mônica Castagna, MARTINS, M. F. A. Coleção Caminhos as Educação do Campo. Belo-Horizonte: Autêntica, 2018 (no prelo).

CORRÊA, Edisa Assunção; ARAÚJO, Maria Ludetana. As classes multisseriadas da comunidade de Bom Jesus, na zona Rural do município de Anapu - PA: os grandes desafios. VII Encontro Nacional das licenciaturas - VII ENALIC. ISSN 2526-3234. V. 1, 2018.

COSTA, Lourenço Resende da. Manifestações de poder e identidade em torno da Língua Ucraniana em Prudentópolis. 2013. 152f. Dissertação (Mestrado em História). Universidade Estadual do centro-oeste. Irati, 2013.

D’ÁVILA, Fernanda; FACHIN, Gleisy, R. B. O lúdico literário nas bibliotecas escolares. In: BLATTMANN, Ursula; VIANNA, Willian Barbosa. Inovação em escolas com bibliotecas. Florianópolis: Dois por Quatro, 2016. 


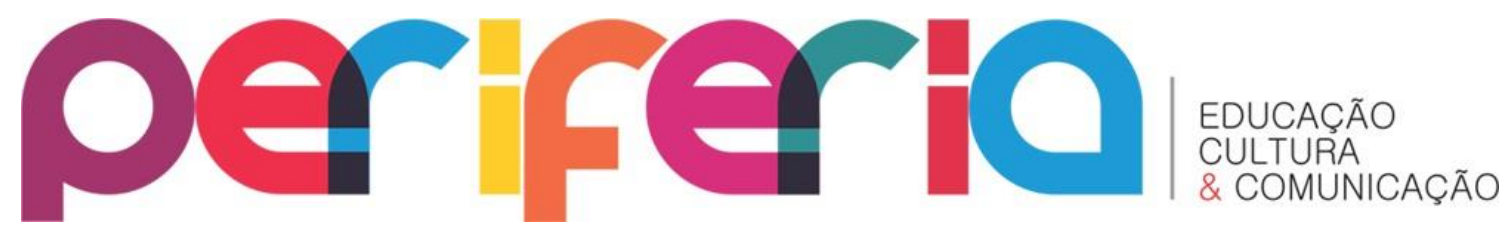

ISSN:1984-9540

DOI: 10.12957/periferia.2021.55242

FERRAREZI JR, Celso; CARVALHO, Robson Santos de. De alunos a leitores: o ensino da leitura na educação básica. 1. ed. São Paulo: Parábola Editorial, 2017.

FREITAS, Luis Carlos de. Ciclos, seriação e avaliação: confrontos de lógicas. São Paulo: Moderna, 2003.

GERALDI, João Wanderley. Concepções de linguagem e ensino de Português. In: O texto na sala de aula. João Wanderley Geraldi (Organizador). 4. ed. São paulo: Ática, 2006. p. 39-46.

HAGE, Salomão Antônio Mufarreg. Transgressão do paradigma da (multi)seriação como referência para a construção da escola pública do campo. Educ. Soc., Campinas, v. 35, n 129, p. 1165-1182, out.-dez.,2014.

IPARDES, Instituto Paranaense de Desenvolvimento Econômico e Social. Caderno Estatístico município de Prudentópolis. Curitiba: Ipardes, 2019.

MIRANDA, Ilcéia de Sousa. O ensino de leitura nas classes de multianos de escolarização dos anos iniciais do Ensino Fundamental, Cametá-PA. In: Educação e Desenvolvimento Regional: desafios e perspectivas / Organizado por Cezar Luís Seibt, José Pedro Garcia Oliveira, Doriedson do Socorro Rodrigues. Cametá: CUNTINS, 2011.

MST. Mais de 4 mil escolas do campo fecham suas portas em 2014. Disponível em: http://www.mst.org.br/2015/06/24/mais-de-4-mil-escolas-do-campofecham-suas-portas-em2014.html. Acesso em: 10/10/2020

PARANÁ. Secretaria de Estado da Educação. Ensino fundamental de nove anos: orientações pedagógicas para os anos iniciais - Língua Portuguesa. Ângela Mari Gusso [et al.] / organizadores: Arleandra Cristina Talin do Amaral, Roseli Correia de Barros Casagrande, Viviane Chulek. Curitiba-PR, 2010.

PIANOVSKI, Regina Bonat. Ensino e aprendizagem em escolas rurais multisseriadas e as contribuições da psicologia histórico-cultural e da pedagogia histórico-crítica. 2017. 225f. Tese (Doutorado em Educação). Programa de pós-graduação em Educação. Universidade Tuiuti do Paraná. Curitiba: 2017.

ROSA, Vanessa Makohin Costa. Políticas linguísticas e multilinguismo em uma escola do interior do Paraná. 2017. 175f. Dissertação (Mestrado em estudos da Linguagem). Programa de Pós-graduação em estudos da linguagem, Universidade Estadual de Ponta Grossa. Ponta Grossa, 2017.

SANTOS, Fábio Josué Souza; MOURA, Terciana Vidal. Políticas educacionais, modernização pedagógica e racionalização do trabalho docente:

problematizando as representações negativas sobre as classes multisseriadas. In: Escola de direito: reinventando a escola multisseriada / Maria Isabel 


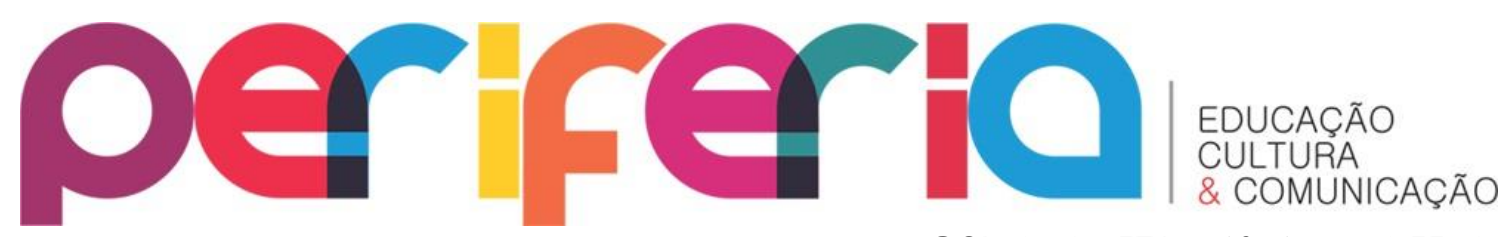

ISSN:1984-9540

DOI: 10.12957/periferia.2021.55242

Antunes-Rocha, Salomão Mufarrej Hage (Organizadores). Belo Horizonte:

Autêntica, 2010. p. 35-48.

SILVA, Ezequiel Theodoro. Elementos da Pedagogia da leitura. $3^{a}$ ed. São Paulo: Martins Fontes, 1998.

SILVA, Ezequiel Theodoro. Leitura na escola e na biblioteca. 4. Ed. Campinas SP: Papirus, 1993.

SILVA, Janaine Zdebski; HAMMEL, Ana Cristina; BORSATO, Michele. Escolas multisseriadas e escolas itinerantes do Paraná: o direito e a resistência. In: Formação continuada de educadores da educação básica na região centro-sul do Paraná: a experiência do Programa Escola da Terra / Ana Cristina Hammel, Marcos Gerhke, Alex Verdério (Organizadores). Tubarão: Ed. Copiart, 2016. p. 21-70.

VIGOTSKY, L. Pensamento e Linguagem. São Paulo: Martins Fontes, 1988.

WINCHUAR, Marcio José de Lima. Práticas de leitura em escolas do campo: um estudo com professores de escolas e classes multisseriadas de PrudentópolisPr. 2020. 242f. Tese (Doutorado em educação), Universidade Federal do Paraná, Curitiba, 2020. 